\title{
Syllabus: Hip Hop Theater
}

\section{By Djola Branner (Hampshire College) and Priscilla Page (UMASS Amherst)}

This course examines the influence of Hip Hop music, dance and visual art on the content and character of contemporary American drama. Primary considerations are identifying this "new" aesthetic, its origins and major players, and exploring the convergence of art, culture, politics and community. We will analyze the works of such theatre artists as Will Power, Renita Martin, Rennie Harris, Kamilah Forbes, Marc Bamuthi Joseph and Universes. We will take a close look at the cultural, social, and political conditions in place at the time of Hip Hop's genesis and consider the political nature of Hip Hop as culture and how and when its political roots are acknowledged by contemporary artists

\section{Course Curriculum:}

Chang, Jeff. Can't Stop, Won't Stop: A History of the Hip Hop Generation

Euell, Kim. Plays from the Boombox Galaxy

\section{Week 1}

Introductions; Review of Syllabus; What is Hip Hop?

1st Assignment: Each student will bring in something that exemplifies Hip Hop. This could be aural, visual, performative; spoken or written. Limit the presentation to 5 minutes.

\section{Week 2}

Share 1st Assignment, Group 1.

Share 1st Assignment, Group 2.

\section{Week 3}

Lecture/Discussion - Can't Stop, Won't Stop by Jeff Chang, Chapter 1

Film excerpt: Style Wars

\section{Week 4}

Lecture/Discussion - Can't Stop, Won't Stop, Chapters $9 \& 10$

In-Class Response \#1: Last Poets \& Gil Scott Heron

Lecture/Discussion - Can't Stop, Won't Stop, Chapter 11

1st Critical Response Due.

\section{Week 5}

In-Class Response: "a/coltrane/poem" by Sonia Sanchez and "Black Art" by

Amiri Baraka; Film Excerpt: Style Wars

Lecture/Discussion - for colored girls who have considered suicide/when the rainbow is enuf by Ntozake Shange (electronic copy)

\section{Week 6}

Lecture/Discussion - Can't Stop, Won't Stop, Chapters $18 \& 19$

"Can You Rock It Like This" by Holly Bass in The Fire This Time, edited by Vivien Labaton and Dawn Lundy Martin (electronic copy)

Peer Review Comments Due

\section{Week 7}

Goddess City by Abiola Abrams \& Antoy Grant in Say Word: Voices from copy)

Hip Hop Theater, edited by Daniel Banks (electronic

2nd Critical Response: White Chocolate for My Father by Laurie Carlos 


\section{Week 8}

Spring Break

\section{Week 9}

Lecture/Discussion: What is Hip Hop Theater?

"Shango's Mixtape", Introduction to Plays from the Boombox Galaxy by Kim Euell

In Case You Forget by Ben Snyder (electronic copy); group one presents

1st Critical Response, second draft due

\section{Week 10}

"Minstrel Reprise: Hip Hop and the Evolution of the Black Image in American Popular Culture" by Jeffrey Ogbar presents

Welcome to Arroyo's by Kristoffer Diaz; group two

\section{Week 11} Rose

Preface and Introduction to The Hip Hop Wars by Tricia

In-Class Response: "Blink Your Eyes" by Sekou Sundiata on Long Story Short, Righteous Babe Records, 2000; and "No Black Male Show" by Carl Hancock Rux on Rux Revue, 55 Music, 1999.

"World Wide Hip Hop Art Beyond Borders" by Chang (electronic copy)

3rd Critical Response

\section{Week 12}

Low by Rha Goddess (electronic copy); group three presents

The Evidence of Silence Broken by Zell Miller III in Plays from the Boombox Galaxy, group four presents

\section{Week 13}

Flow by Will Power in Plays from the Boom Box Galaxy, group five presents

Attend Hip Hop and Theater panel, performance \& discussion with Zell Miller III, Curtain Theater

Class Discussion of Panel and Performance

\section{Week 14}

"word becomes flesh" by marc bamuthi joseph in Plays from the Boom Box
Galaxy, group six presents

Portfolio (with all course work) and Final paper (10 pages) due.

\section{Hip Hop and Theater Course Bibliography}

1. Style Wars produced by Public Art Films, 2004.

2. Banks, Daniel. Say Word: Voices from Hip Hop Theater. The University of Michigan Press, 2011.

3. Carlos, Laurie. White Chocolate for My Father in Moon Marked and Touched By Sun edited by Sydne Mahone. Theater Communications Group, 1994.

4. Chang, Jeff. Total Chaos: The Art and Aesthetics of Hip Hop. Basic Civitas, 2007.

5. Chang, Jeff. Can't Stop, Won't Stop: A History of the Hip Hop Generation. St. Martin's Press, 2005.

6. Elam, Harry. Taking It to the Streets: The Social Protest Theater of Luis Valdez and Amiri Baraka. University of Michigan Press, 1997.

7. Euell, Kim. Plays from the Boombox Galaxy: Theater from the Hip Hop Generation. Theater Communications Group, 2009.

8. Forbes, Kamilah. Rhyme Deferred in The Fire This Time: African American Plays for the 21st Century edited by Harry Elam, Jr. and Robert Alexander. Theater Communications Group, 2002.

9. Jones, LeRoi. "The Revolutionary Theater." http://www.nathanielturner.com/revolutionarytheatre.htm

10. Jones, Omi Osun Joni L., Lisa Moore and Sharon Bridgforth. Experiments in a Jazz Aesthetic: Art, Activism, Academia, and the Austin Project. University of Texas Press, 2010.

11. Ogbar, Jeffrey O. G. Hip Hop Revolution: The Culture and Politics of Rap. University Press of Kansas, 2007.

12. Rose, Tricia. The Hip Hop Wars: What We Talk About When We Talk About Hip Hop and Why It Matters. Basic Books, 2008.

13. Rux, Carl Hancock. Rux Revue. 55 MUSIC, 1999.

14. Sanchez, Sonia. Homegirls and Handgrenades. Thunder's Mouth Press, 1984.

15. Sapp, Steven and Mildred Ruiz. Slanguage in The Fire This Time: African American Plays for the 21st Century edited by Harry Elam, Jr. and Robert Alexander. Theater Communications Group, 2002.

16. Scott-Heron, Gil. The Revolution Will Not Be Televised. Bluebird/RCA, 1988.

17. Sundiata, Sekou. Long Story Short. Righteous Babe Records, 2000. 